\title{
Creation of anticancer drugs employing metal-containing macromolecules
}

\author{
Charles EC Jr' ${ }^{*}$, Michael RR ${ }^{2}$ \\ ${ }^{1}$ Department of Chemistry and Biochemistry, Florida Atlantic University, Boca Raton, Florida, USA \\ ${ }^{2}$ Department of Biology, University of Texas at Arlington, Arlington, Texas, USA
}

\begin{abstract}
In order to simulate cancer growth rate, travelling wave migration effects and effects of chemotherapy on given initial number of cancer cells, the following calculations have been done to estimate the effectiveness of the dosage of chemotherapy. Using this method any appropriate function could be used to estimate cancer growth, cancer travelling wave migration and chemotherapy.
\end{abstract}

\section{Introduction}

This brief paper describes the use of metal-containing polymers such as platinum derivatives of cisplatin, organotin polymers, group 15, and group 4 metallocene-containing polymers as potential anticancer macromolecules.

\section{Strategy}

As metals are essential sites for many biologically important macromolecules, such as chlorophyll and hemoglobin, it is reasonable to assume metals can play important roles in the curtailment of unwanted diseases as cancer. The Lewis acid metal-containing monomers we employ all exhibit some biological activity. The Lewis acids are reacted with Lewis bases that also exhibit biological activity hoping for a synergetic effect.

The focus is also on commercially available reactants allowing ready scale up and replication of our work. It also allows a minimum of startup time since we are not involved in the often-time-consuming syntheses often required to produce the needed reactants. There are many possible reactants that wait to be formed into polymers that can exhibit desired biological activity. Our focus here is on inhibiting cancer. Even so our materials also show good inhibition of mildew, rot, bacteria, and viruses.

The reaction system generally used for all, but the platinum systems is called the interfacial polycondensation process that is used commercially to produce polycarbonates and aramid fibers [1,2]. It employs simple instrumentation, a commercial Waring blender, generally giving product within less than a minute.

\section{Cell growth indicators}

Two cell growth indicator measurements are normally employed to measure the ability of the test compound to curtail cell growth. Both involve the concentration, dose, needed to reduce the growth of the particular cell line. The first measurement is often referred to as effective concentration, EC, values though different symbols/names are used. The concentration of a drug, antibody, or toxicant that induces a response halfway between the baseline and maximum after a specified exposure time is referred to as the $50 \%$ response concentration and is given the symbol $\mathrm{EC}_{50}$.

The second measure of the potential use of compounds is the concentration of drug necessary to inhibit the standard cells compared to the concentration of drug necessary to inhibit the growth of the test cell line. Again, a variety of symbols are employed to describe similar calculations. We generally employ the term chemotherapeutic index, $\mathrm{CI}$, so that the $\mathrm{CI}_{50}$ is then the ratio of the $\mathrm{EC}_{50}$ for the standard cell line typically NIH/3T3 or WI-38 cells divided by the $\mathrm{EC}_{50}$ for the particular test cell.

Generally, the lower the $\mathrm{EC}_{50}$ values and higher the $\mathrm{CI}_{50}$ values the greater the possibility that the test compounds offer good inhibition and is in line for further testing.

\section{Advantages of macromolecular drugs}

There are a number of advantages generally given as to why polymeric drugs are preferred [3-15]. Following is a brief description of some of these.

- Macromolecules can have several types of units within them each directing different "missions". Thus, one unit might direct the drug to a particular part of the body; another carries the portion to inhibit cancer growth; and finally, another to improve solubility.

- Because of size, it is more difficult to readily pass though body membranes. Restricted movement may discourage buildup in essential organs as kidneys decreasing renal and another organ damage.

${ }^{\star}$ Correspondence to: Charles EC Jr., Department of Chemistry and Biochemistry, Florida Atlantic University, Boca Raton, Florida, USA, Tel: 954-755-2768; Email: carraher@fau.edu

Key words: cancer, pancreatic cancer, breast cancer, drugs, polymeric drugs, macromolecular drugs, metal-containing drugs, cisplatin

Received: February 15, 2018; Accepted: April 17, 2018; Published: April 20, 2018 
- If controlled delivery of the active agent is important then retention is important allowing a slower sustained delivery. In our case, polymers are believed to act without degradation with the macromolecules being stable in solution for weeks to months.

- Where activity involves multiple bonding to tumor-related sites, there is greater opportunity for such bonding occurring for macromolecules.

- Size can be important in isolating the drug-delivering macromolecule from unwanted events as hydrolysis. Size acts to protect the polymer from bodily surroundings.

- The large size may also assist in bypassing cellular defense.

After chemo treatment, the invasion of chemo drugs generally causes a buildup of so-called "housekeeping" proteins that are generally not particularly selective in their ability to select and remove foreign molecules in the cell. This may be a principle reason why chemo treatments often led to a resistance to the drugs, even drugs that had appeared to be successful. Large size may act against this because these proteins are familiar with smaller invading agents, but not familiar with large invading macromolecules discouraging ready removal by the housekeeping proteins. We have found this because our macromolecules inhibit cell lines that have already been found to be resistant to further chemo treatment by monomeric chemo drugs. G. Cancer cells tend to be less well composed creating uneven cell gaps. These cancer cells have greater permeability and leakage. Large molecules accumulate in these cell gaps more than in normal tissues because of the enhanced permeability and retention effect, resulting in high amounts of polymers residing in the interstitial space due to the leaky vasculature and limited lymphatic drainage typical of tumors. This effect is called the enhanced permeability and retention effect, EPR effect.

There are also reasons why polymeric drugs are not preferred. These include the possibility that chain length will have a marked effect on the biological activity. For our product, most have chain length greater than 500 and the overall anticancer activity is generally independent of their chain length. Second, they are often poorly soluble particularly in water. Drug solubility is a continued problem for both small and large molecules. For instance, industrially most drugs are tested after dissolving them in dimethy sulfoxide, DMSO. These solutions then have water added resulting a test solution that is typically over $90 \%$ water, for us over $99 \%$ water. Even so, there is good evidence that in some cases the presence of even the small about of DMSO can have dramatic effect on the cell activity. We generally do not find this to be a problem. There exists greater possible variation in biological results for polymers since the macromolecules are of chains of varying lengths and the polymer can have embedded in them unknown and unwanted chemical agents. Again, we find this not to be a problem.

\section{Cisplatin Macromolecules}

Only two metal-containing compounds have undergone human cancer treatment testing. We work with both and will make comments on both as well as other metal-containing products emphasizing polymeric materials. The two metals are platinum forming the basis of the cis-dichloroplatinum II diamine, cisplatin, compounds, and titanocene-based small molecules.

Cisplatin compounds have been employed as anticancer agents since the late 1960s. In 1964 Rosenberg and co-workers discovered that in the presence of platinum electrodes E. coli failed to divide but continued growing, giving filamentous cells [16]. While effective they, and most anticancer agents, have horrific side effects including gastrointestinal, auditory, hematopoietic, immunosuppressive, and renal dysfunction. The topic of cisplatin and related platinum derivatives as anticancer drugs has been reviewed [15, 17-19]. They are employed in the treatment of a wide variety of cancers including ovarian cancer, breast cancer, bladder cancer, testicular cancer, neutoblastome tumors, brain tumors, lung cancer, esophageal cancer and head and neck cancer. Structures of the most widely platinum-employed drugs are given in Figure 1.

In an effort to lower toxicity cis-platin-like structures were incorporated into polymers hoping to benefit from the presence of the active platinum site in the polymer. The macromolecular products are made by simply mixing in an aqueous solution the tetrachloroplatinum II salt and the Lewis base such as the known anticancer drug methotrexate. The product precipitates because as the chain grows it becomes less soluble precipitating at some point. This polymer was tested, along with a few others of ours, by Bristol Laboratory for the ability to inhibit L1210 Leukemia in mice utilizing a value called the $\% \mathrm{~T} / \mathrm{C}$, which is defined as the median survival time for treated mice divided by the median survival time for the control times one hundred. The methotrexate polymer, showed a $\% \mathrm{~T} / \mathrm{C}$ of 164 at a dosage of 16 $\mathrm{mg} / \mathrm{kg}$ (Figure 2).

Two of the platinum polyamines were tested more extensively against normal and transformed cells. Polymers in which the diamine component was methotrexate or 2-chloro-p-phenylenediamine were used to treat a variety of mouse Balb/3T3 cells, including normal nontumorigenic cells, spontaneously transformed tumorigenic cells, and virus-transformed tumorigenic cells. When treated with the polymer containing 2-chloro-p-phenylenediamine, all cell types were actively<smiles>N[PH](N)(N)Cl</smiles><smiles>N[PH3][PH](N)(N)OC(=O)C12CCC1C2=O</smiles><smiles>N[PH3](N)(N)OCC(=O)O</smiles><smiles></smiles>

Figure 1. Structures of cisplatin-related drugs (Cisplatin, Carboplatin, Nedaplatin and Oxaliplatin) currently employed in treating cancer.

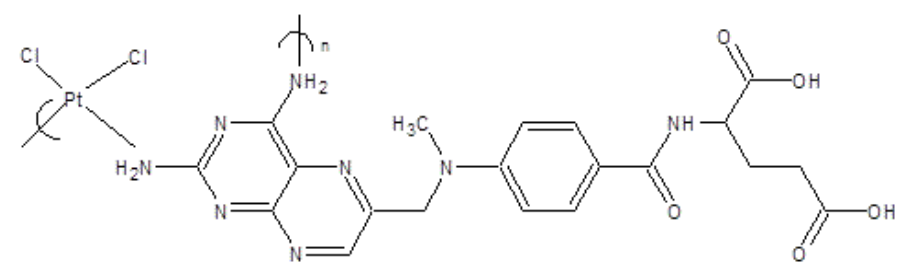

Figure 2. Structure of the product of tetrachloroplatinate II and methotrexate. 
killed at a concentration of $10 \mu \mathrm{g} / \mathrm{mL}$. Cell growth was inhibited $50 \%$ at a concentration of $5.0 \mu \mathrm{g} / \mathrm{mL}$. However, normal quiescent Balb/3T3 cells were unaffected by polymer concentrations as high as $20 \mu \mathrm{g} / \mathrm{mL}$, indicating that cells must be actively growing in order for the polymer to exert its effects. This would be consistent with a mechanism of polymer action involving the inhibition of DNA replication, similar to that of cisplatin. The polymer containing methotrexate gave similar results, except that this polymer was far more active, killing the various cell types at a concentration of $0.5 \mu \mathrm{g} / \mathrm{mL}$ and inhibiting cell growth $50 \%$ at a concentration of $0.06 \mu \mathrm{g} / \mathrm{mL}$. Again, normal quiescent cells were resistant to the polymer. The stronger activity of this polymer demonstrates the advantage of combining two different anti-cancer agents in one compound.

To investigate the structure-activity relationship of the platinum polyamines, about two dozen different polymers were synthesized, each with a different diamine component. The diamines varied from relatively simple ones, such as 2-nitrophenyldiamine and 2,5-diaminopyridine, to rather complex structures including tilorones and acridines. The biological activity of these polymers was tested using Balb/3T3 cells, and a wide range of activity was found. Some polymers were essentially inactive, showing no effect on cell growth at concentrations up to $50 \mu \mathrm{g} / \mathrm{mL}$. The diamine components of these inactive polymers included amino acids and pyridine derivatives. Other polymers were extremely active, significantly inhibiting cell growth at concentrations of $0.1-1.0 \mu \mathrm{g} / \mathrm{mL}$. The diamine components of these very active polymers included tilorone, proflavin, euchrysine, and acridine yellow, as well as methotrexate. In addition to affecting normal Balb/3T3 cells, these polymers also inhibited the growth of various human ovarian cancer cell lines.

The more active metallocene-containing polymers were comparable to cisplatin in their biological effects, killing or inhibiting the growth of a variety of actively growing cells at similar concentrations, but having little effect on quiescent cells. In one respect, however, the polymers differed significantly from cisplatin. The activity of a cisplatin solution depends upon the age of the solution [15]. While fresh solutions of cisplatin in DMSO or water are very active, solutions stored one week, even at $4^{\circ} \mathrm{C}$, are 100 -fold less active. This is due to reaction of the cisplatin with the solvent, forming substituted charged species that cannot easily enter the cell. In contrast, the age of macromolecular solutions does not affect its biological activity for short term. Polymer solutions in DMSO stored for one week at room temperature showed the same effects on cells at the same concentrations as did freshly prepared solutions.

Another concern involves the toxicity of the metal-containing moieties. The toxicity of the metal-containing units varies with the precise compounds as well as mode of measurement and test animal. For cisplatin the $\mathrm{LD}_{50}$ are as follows-Rat oral $25.8 \mathrm{mg} / \mathrm{kg}$; Rat Intravenous $8.0 \mathrm{mg} / \mathrm{kg}$; mouse oral $32.7 \mathrm{mg} / \mathrm{kg}$; and mouse intravenous $11 \mathrm{mg} / \mathrm{kg}$ (Pfizer Material Safety Data Sheet). For titanocene dichloride the $\mathrm{LD}_{50}$ values are rat intraperitoneal $25 \mathrm{mg} / \mathrm{kg}$ and mouse intravenous $180 \mathrm{mg} / \mathrm{kg}$ (TCI America Material Safety Data Sheet). For zironocene dichloride the rat $\mathrm{LD}_{50}$ intraperitoneal is $30 \mathrm{mg} / \mathrm{kg}$ (TCI America Material Safety Data Sheet). For hafnocene dichloride the $\mathrm{LD}_{50}$ is given as intravenous mouse at $100 \mathrm{mg} / \mathrm{kg}$ (TCI America MSD). Toxicity is dependent on a number of items including mode of administration. While exact matches are not available, it appears that cisplatin has lower $\mathrm{LD}_{50}$ values, is more toxic, than any of the metallocene dichlorides by about three-fold.

\section{Metallocene Macromolecules}

The second metal undergoing human studies as anticancer drugs is titanium. Here, we look at the Group 4 metallocenes, titanocene, zirconocene, hafnocene, as anticancer agents. The literature shows millions of references to these metallocenes because of their use as catalysts in the formation of many of today's materials including polystyrene, polypropylene, and polyethylene. Their use as anticancer agents is much less referenced.

In preclinical studies titanocene dichloride inhibited the ovarian cancer cell line A2780 CP3 that was twenty-fold resistant to cisplatin while the cell line was only about two and a half resistant to titanocene dichloride indicating an absence of cross-resistance between the two metal containing drugs [20]. This is consistent with the finding for in vivo studies where titanocene dichloride showed much greater ability to inhibit cisplatin resistant human ovarian cancer xenografts compared to cisplatin. Further, titanocene dichloride largely overcame cisplatin resistance for the $\mathrm{A} 2780 \mathrm{CP}$ and $\mathrm{CH} 1$ cisR ovarian cancer cell lines in bcl-2 and p53 transfectants of A2780 cells [21].

Titanocene dichloride underwent Phase I clinical trials. The trials indicated a dose-limiting side effect associated with nephrotoxicity and a number of unwanted physical side effects including nausea, reversible metallic taste, pain during infusion, hypoglycemia, with these features undesirable. Counter, the absence of an effect on proliferative activity of the bone marrow, generally a dose-limiting side effect, was positive. Some phase II clinical trials were undertaken with patients with breast metastatic carcinoma [22-24] and advanced renal cell carcinoma [25]. Unfortunately, low activity discouraged further clinical study. Also limiting much continued study was the poor solubility of the titanocene derivatives.

A number of studies are consistent with DNA-metallocene interactions, including titanocene dichloride, zirconocene dichloride, and hafnocene dichloride, being a major determinant in the anticancer activity of these materials [22].

There is a difference between structural dependencies of our compounds and many metallocenes. It was concluded by some studies that the metallocene dichlorides themselves required liability of the chlorides for activity but our compounds exhibit their activity as polymers rather than control delivery of small units [15,23]. Other studies have demonstrated anticancer activity when the halides are replaced so these conclusions are premature [15].

As noted before cisplatin is among the most widely employed chemo-agents. It is included in our studies as a standard. Consistent with other studies done by us the metallocene monomers are relatively non-toxic [26-30] as is the Lewis base. Even so, the ability of various Group 4 metallocene small molecules to inhibit cancer growth is well established [22-25,31-36]. In fact, as previously noted, titanocene dichloride was the first-non-platinum metal-containing compound to undergo clinical trial [37]. The mechanism by which it inhibits cell growth is complex and not fully understood but is believed to be related to the metallocene's ability to interact with the protein transferrin $[37,38]$.

One goal is to offer macromolecules that inhibit pancreatic cancer. There is no effective treatment of pancreatic cancer once it metastasizes. In the USA yearly about 32,000 new cases are diagnosed. Within a year almost all of these die. Worldwide, it is the fourth leading cause of cancer death. We have found that inhibition of pancreatic cancer cell lines is difficult compared with other human cancer cell lines. Even so, we found a number of macromolecules that exhibit good ability 
to inhibit pancreatic cancer. We employ the two most widely studied human pancreatic cancer cell lines in our studies. The tested cell lines are AsPC-1 which is an adenocarcinoma pancreatic cell line, which accounts for about $80 \%$ of the diagnosed human pancreatic cancers, and PANC-1 which is an epithelioid carcinoma pancreatic cell line, accounting for about $10 \%$ of the human pancreatic cancer cases.

Typically, in comparison to organotin macromolecules, analogous polymers derived from the same Lewis base, have lower $\mathrm{EC}_{50}$ values some in the nanogram $/ \mathrm{mL}$ range and higher $\mathrm{CI}_{50}$ values many in the teens and hundreds. Further, the general order of activity is $\mathrm{Hf}$ about the same as $\mathrm{Zr}$ and both greater than $\mathrm{Ti}$ for the same Lewis base. As in the case with small metallocene compounds, they are difficultly soluble in any solvent, but sufficiently soluble in DMSO allowing cell inhibition, NMR, and chain length studies to occur. We have found that the hafnocene and zirconocene polymers have better solubility in DMSO compared with titanocene polymers.

Following are sample results for the product of alpha-cyano-4hydroxycinnamic acids and the Group 4 metallocenes, Figure 3, for the two pancreatic cancer cell lines that illustrate the general comments given above [39].

Briefly, the data in Table 1 shows that the $\mathrm{EC}_{50}$ values for the zirconocene and hafnocene polymers are in the nanogm $/ \mathrm{mL}$ range and less than that found for the titanocene polymer and cisplatin. Second, the $\mathrm{CI}_{50}$ values for the zirconocene and hafnocene polymers are larger and then those found for the titanocene polymer and cisplatin. Finally, when human testing was done, it should have been done with zirconocene and hafnocene products and not titanocene. Presumably, the scientists performing the human tests were not aware of the benefits that were possible using the other two metallocenes in this family. This points to the need to have chemists as members of the overall medical community dealing with cancer drugs (Table 1).

\section{Organotin Macromolecules}

Knowledge of organotin compounds inhibiting the growth of tumors has been known for nearly 90 years. The ability to inhibit cancer cells in some coordinated manner has not been systematically undertaken though there have been well over 1,000 studies cited in SciFinder Scholar. It was suspected that the mechanism of tumor inhibition was similar to that of platinum because of a similar bond angle between organotin and cisplatin but this has been shown to be wrong [40].

The study of organotin polymers as anticancer agents has only relatively recently been undertaken and has been reviewed $[41,42]$. Sites for organotin antitumor activity have been several $[41,42]$. These include pseudochiasmata in the chromosomes, inhibition of macromolecular synthesis and mitochondrial energy metabolism, reduction of DNA synthesis, etc. In fact, it is found that there is a variation as to the perceived active site for different cell lines and different organotin compounds. While disappointing, it is consistent with the difficulty of pinning down active sites for even well-known drugs such as cisplatin

Table 1. Inhibition results for the product of alpha-cyano-4-hydroxycinnamic acid, CHA, and metallocene dichlorides.

\begin{tabular}{|c|c|c|c|c|}
\hline & \multicolumn{2}{|c|}{ PANC-1 } & \multicolumn{2}{c|}{ AsPC-1 } \\
\hline Compound & $\mathbf{E C}_{\mathbf{5 0}}$ & $\mathbf{C I}_{\mathbf{5 0}}$ & $\mathbf{E C}_{\mathbf{5 0}}$ & $\mathbf{C I}_{\mathbf{5 0}}$ \\
\hline $\mathrm{Cp}_{\mathbf{2}} \mathrm{Ti} / \mathrm{CHA}$ & 0.071 & 32 & 0.055 & 42 \\
\hline $\mathrm{Cp}_{2} \mathrm{Zr} / \mathrm{CHA}$ & 0.001 & 1000 & 0.00097 & 1600 \\
\hline $\mathrm{Cp}_{2} \mathrm{Hf} / \mathrm{CHA}$ & 0.0011 & 1700 & 0.0058 & 330 \\
\hline Cisplatin & 0.0023 & 8.3 & 0.0035 & 5.5 \\
\hline
\end{tabular}

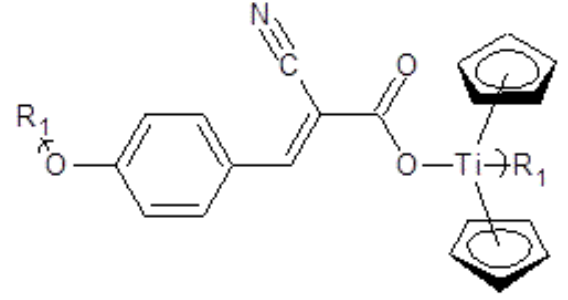

Figure 3. Repeat unit for the product of alpha-cyano-4-hydroxycinnamic acid, CHA, and titanocene dichloride where R1 represents simple chain extension.

where we believe one of the major sites involves cross-linking of growing DNA, but additional data continues to be published.

We have synthesized and tested organotin macromolecules against a variety of cancer cell lines a wide variety of organotin-containing polymers [41,42]. These polymers generally exhibit decent inhibition of all tested cell lines including those associated with pancreatic cancer. While the $\mathrm{EC}_{50}$ values are decent the $\mathrm{CI}_{50}$ values are variable with some exhibiting values in the 1 to 2 range, some exhibit values much greater. The greater the $\mathrm{CI}_{50}$ value the greater the differentiation between the standard cell line, generally WI38 cells, and the test compound. Recently we have found good $\mathrm{CI}_{50}$ values for polymers derived from Lewis bases such as camphoric acid, etc. Table 2 contains results for some of our recent work with the synthetic nucleic acid thymidine and various organotins (Figure 4) [43].

\section{Group 13 containing macromolecules}

We have also have made a number of Group 13 organometallic polymers from triphenylarsenic, triphenhylantimony, triphenylbismuth dihalides. Figure 5 contains the repeat unit for the product of triphenylantimony dichloride and 3,5-pyridinedicarboxylic acid. These polymers exhibit decent $\mathrm{EC}_{50}$ and $\mathrm{CI}_{50}$ values but not as good as the organotin polymers.

Overall the best $\mathrm{EC}_{50}$ and $\mathrm{CI}_{50}$ values are for the metallocenes, followed by the organotin, followed by the Group 13 products with respect to $\mathrm{EC}_{50}$ and $\mathrm{CI}_{50}$ values.

An additional comment, the EC values are calculated from a plot of concentration verses amount inhibited. Once inhibition begins, there is a rapid decrease in the curve ending at total inhibition [44-48].

\section{Water soluble polymers}

Compared with smaller molecules, polymer solubility is more limited with respect to variety of solvents that can dissolve them and the extent of solubility. By comparison, the solubility of metalcontaining polymers is even more difficult. Thus, one major problem with polymers in general and metal-containing polymer in particular is poor solubility, and specifically lack of aqueous solubility. This has limited progress in a number of areas. We have been working to overcome this. Our efforts at this have been recently reviewed [49]. Our primarily approach is the incorporation of poly (ethylene glycol) (PEG; also called poly (ethylene oxide), PEO) into the polymer chain to allow the polymer combination, copolymer, to become soluble. The use of PEG to assist in polymer solubility is not new [50-52].

Recently, we synthesized a number of organotin-containing polymers employing PEG producing water soluble polymers [53-55]. We simply employed the PEG as the Lewis base in our reaction system. Recently, we similarly produced water soluble polymers containing titanocene, zirconocene, and hafnocene units [49,56,57]. 
Currently we are beginning synthesis of co-polymers aimed at producing water soluble products containing Lewis bases that exhibit outstanding biological activity so that these macromolecules will be available as water soluble drugs for testing and possibility eventually used more widely.

Essentially, the Lewis acid is polymerized with the desired Lewis base, to be incorporated into the polymer, along with an appropriate PEG molecule. The overall scheme is pictured in Figure 6 for one of the polymers, here containing the camphoric acid moiety that offers good

Table 2. Inhibition results for the product of alpha-cyano-4-hydroxycinnamic acid, CHA, and metallocene dichlorides.

\begin{tabular}{|c|c|c|c|c|}
\hline & \multicolumn{2}{|c|}{ PANC-1 } & \multicolumn{2}{c|}{ AsPC-1 } \\
\hline Compound & $\mathbf{E C}_{\mathbf{5 0}}$ & $\mathbf{C I}_{\mathbf{5 0}}$ & $\mathbf{E C}_{\mathbf{5 0}}$ & $\mathbf{C I}_{\mathbf{5 0}}$ \\
\hline $\mathrm{Me}_{2} \mathrm{Sn} / \mathrm{TH}$ & 0.25 & 1.8 & 0.23 & 2 \\
\hline $\mathrm{Et}_{2} \mathrm{Sn} / \mathrm{TH}$ & 0.13 & 3.5 & 0.12 & 3.8 \\
\hline $\mathrm{Bu}_{2} \mathrm{Sn} / \mathrm{TH}$ & 0.24 & 1.9 & 0.22 & 2.1 \\
\hline $\mathrm{Oc}_{2} \mathrm{Sn} / \mathrm{TH}$ & 0.23 & 1.9 & 0.22 & 1.9 \\
\hline $\mathrm{Ph}_{2} \mathrm{Sn} / \mathrm{TH}$ & 0.2 & 2.2 & 0.22 & 2 \\
\hline
\end{tabular}

The $\mathrm{EC}_{50}$ and $\mathrm{CI}_{50}$ values are good but not as good as the metallocene values.<smiles>[R][Y](CC)(CC)OCC1OC(n2cc(C)c(=O)[nH]c2=O)CC1O[Z20]CC</smiles>

Figure 4. Reaction between diethyltin dichloride and thymidine, TH, where R represents simple chain extension.

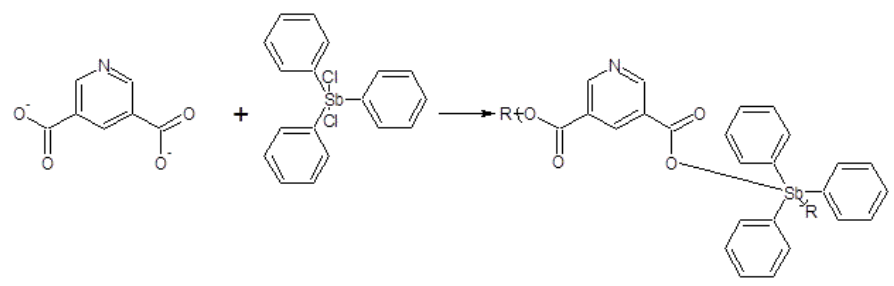

Figure 5. Reaction between the salt of 3,5-pyridinedicarboxylic acid and triphenylantimony dichloride were $\mathrm{R}$ represents simple chain extension.

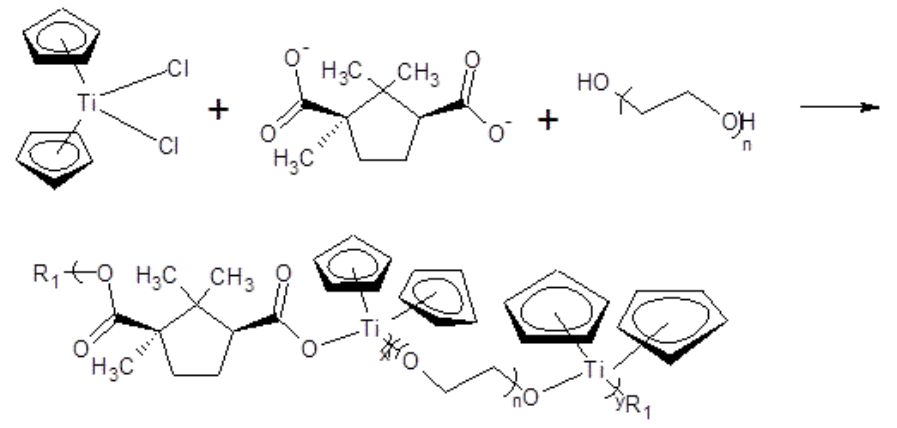

Figure 6. Reaction between titanocene dichloride and the salt of camphoric acid and poly(ethylene glycol). ability to inhibit cancer cell lines.

\section{Conclusion}

The synthesis and biological characterization of metal-containing macromolecules continues with movement in several areas including a search for products that exhibit low toxicity but outstanding ability to inhibit cancer cell lines, in particular those associated with pancreatic cancer since there exists no ability to successfully treat it once it metastases. We are beginning additional live animal studies. Finally, we are working towards developing an approach that allows salvation of compounds that exhibit outstanding biological properties including ability to inhibit bacteria, mold, viruses, cancer, fungi, etc.

\section{References}

1. Carraher C (2017) Introduction to Polymers. ( $4^{\text {th }}$ Edn), Taylor and Francis, New York.

2. Carraher C (2018) Polymer Chemistry. (10 ${ }^{\text {th }}$ Edn), Taylor and Francis, New York.

3. Alama A, Tasso B, Novelli F, Sparatore F (2009) Organometallic compounds in oncology: implications of novel organotins as antitumor agents. Drug Discovery Today 14: 500-508.

4. Nebbia C, Dacasto M, Ceppa L, Gennaro Soffietti M, Spinelli P, et al. (1997) The comparative effects of subchronic administration of triphenyltin acetate (TPTA) on the hepatic and renal drug-metabolizing enzymes in rabbits and lambs. Vet Res Commun 21: $117-125$.

5. Luo Y, Prestwich GD (2002) Cancer-targeted polymeric drugs. Curr Cancer Drug Targets 2: 209-226.

6. Maeda H (2010) Tumor-selective delivery of macromolecular drugs via the EPR effect background and future prospects Bioconjug Chem 21: 797-802.

7. Fang J, Nakamura H, Maeda H (2011) The EPR effect: unique features of tumor blood vessels for drug delivery, factors involved, and limitations and augmentation of the effect. Adv Drug Deliv Rev 63: 136-151.

8. Torchilin V (2011) Tumor delivery of macromolecular drugs based on the EPR effect. Adv Drug Deliv Rev 63: 131-135.

9. Fish RH (2010) A bioorganometallic chemistry overview: from cytochrome P450 enzyme metabolism of organotin compounds to organorhodium-hydroxytamoxifen complexes with potential anti-cancer properties; A 37-year perspective at the interface of organometallic chemistry and biology. Aust J Chem 63: 1505-1513.

10. Tabassum S, Pettinari C (2006) Chemical and biotechnological developments in organotin cancer chemotherapy. J Organomet Chem 691: 1761-1766.

11. Tiekink ERT (2008) Tin dithiocarbamates: applications and structures. Applied Org Chem 22: 533-550.

12. Appel KE (2004) Organotin compounds: toxicokinetic aspects. Drug Metabol Rev 36 763-786.

13. Nath M, Saini PK (2011) Chemistry and applications of organotin(iv) complexes of Schiff bases. Dalton T 40: 7077-7121.

14. Ulbrich K, Subr V (2004) Polymeric anticancer drugs with $\mathrm{pH}$-controlled activation. Adv Drug Deliv Rev 56: 1023-1050.

15. Siegman D, Carraher C (2004) Polymeric platinum-containing drugs in the treatment of cancer, in Macromolecules Containing Metal and Metal-Like Elements. Wiley pp: 119-192.

16. Rosenberg B, Van Camp L, Krigas T (1965) Inhibition of cell division in Escherichia coli by electrolysis products from a platinum electrode. Nature 205: 698

17. Roner MR, Carraher C, Shahi K, Barot B (2011) Antiviral activity of metal-containing polymers-organotin and cisplatin-like polymers. Materials 4: 991-1012.

18. Roner MR, Carraher C, Dhanju S, Birot G (2008) Antivirial and anticancer activity of cisplatin derivatives of tilorone. J Inorganic Organomet Polym 18: 374-383.

19. Roner MR, Carraher C, Dhanju C, Barot G (2007) Antiviral and anticancer activity of cisplatin derivatives of methotrexate. J Polym Mater 24: 371-385.

20. Harstrick A, Schmoll H, Sass G, Poliwoda H, Rustum Y (1993) Titanocendichloride activity in cisplatin and doxorubicin-resistant human ovarian carcinoma cell lines. Eur J Cancer 29: 1000-1002. 
21. Christodoulou CV, Eliopoulos AG, Young LS, Hodgkins L, Ferry DR, (1998) Antiproliferative activity and mechanism of action of titanocene dichloride. $\mathrm{Br} \mathrm{J}$ Cancer 77: 2088-2097.

22. Murray JH, Harding MM (1994) Organometallic anticancer agents: the effect of the central metal and halide ligands on the interaction of metallocene dihalides Cp2MX2 with nucleic acid constituents. J Med Chem 37: 1936-1941.

23. Harding MM, Mokdsi G (2000) Antitumour metallocenes: structure-activity studies and interactions with biomolecules. Curr Med Chem 7: 1289-1303. [Crossref]

24. Kroger N, Kleeberg UR, Mross K, Edler L, Sab G, et al. (2000) Phase II clinical trial of titanocene dichloride in patients with metastatic breast cancer. Onkologie 23: 60-62.

25. Lummen G, Sperling H, Luboldt H, Otto T, Rubbe H (1998) Phase II trial of titanocene dichloride in advanced renal-cell carcinoma. Cancer Chemo Pharm 42: 415-417.

26. Roner MR, Carraher Jr. C, Shahi K, Ashida Y, Barot G (2009) Ability of group IVB metallocene polyethers containing dienestrol to arrest the growth of selected cancer cell lines. BMC Cancer 9: 358 .

27. Carraher C, Roner MR, Shahi K, Ashida Y, Barot G (2007) Synthesis, structural characterization, and anti-cancer evaluation of group IVB-metallocene polyethers containing the synthetic estrogen diethylstilbestrol. J Polym Mater 24: 357-369.

28. Carraher C (2005) Condensation metallocene polymers. J Inorg Organomet Polym 15: 121-145.

29. Carraher CE, Morrison A, Roner MR, Moric A, Trang N (2014) Synthesis and characterization of organotin polyesters derived from 3,5-pyridinedicarboxylic ccid. $J$ Inorg Organomet Polym 24: 182-189.

30. Carraher C, Truong NTC, Roner MR (2017) Synthesis of metallocene poly(ether esters) from reaction with glycyrrhetinic Acid. J Polym Mater 34: 435-454.

31. Benitez J, Guggeri L, Tomaz I (2009) A novel vanadyl complex with a polypyridyl DNA intercalator as ligand: a potential anti-protozoa and anti-tumor agent. J Inorg Biochem 103: 1386-1394.

32. Strohfeldt K, Tacke M (2008) Bioorganometallic fulvene-derived titanocene anticancer drugs. Chem Soc Rev 37: 1174-1187.

33. Beckhove P, Oberschmidt O, Hanauske A (2007) Antitumor activity of titanoceney against freshly explanted human breast tumor cells and in xenografted mcf-7 tumors in mice. Anticancer Drugs 18: 311-315.

34. Olszewski U, Claffey J, Hogan M, Tacke M, Zeillinger R, et al. (2011) Anticancer activity and mode of action of titanocene C. Invest New Drugs 29: 607-614. [Crossref]

35. Harding MM, Mokdsi G (2000) Antitumour metallocenes: structure-activity studies and interactions with biomolecules. Curr Med Chem 7: 1289-1303.

36. Olszewski U, Hamilton G (2010) Mechanisms of cytotoxicity of anticancer titanocenes. Anticancer Agents Med Chem 10: 302-311. [Crossref]

37. Roat-Malone RM (2007) Bioinorganic Chemistry. (2 Edn), Wiley, New York.

38. Waern JB, Harris HH, Lai B, Cai Z, Harding MM, et al. (2005) Intracellular mapping of the distribution of metals derived from the antitumor metallocenes. J Bio Inorg Chem 10: $443-452$.

39. Carraher C, Roner MR, Ayoub M, Crichton R, Moric-Johnson A, et al. (2016) Synthesis of poly(ester esters) from reaction of alpha-cyano-4-hydroxycinnamic acid and group IVB metallocenes. J Macromol Sci A 53: 328-334.
40. Omae I (1989) Organotin Chemistry. Elsevier, New York

41. Carraher C, Roner MR (2014) Organotin polymers as anticancer and antiviral agents. J Organomet Chem 751:67-82.

42. Carraher C, Siegman-Louda D (2004) Organotin macromolecules as anticancer drugs, in Macromolecules Containing Metal and Metal-Like elements. Biomedical Applications 4: 57-74.

43. Carraher C, Roner MR, Frank J, Chen L (2018) Unpublished results.

44. Carraher C (2008) Organoantimony-containing polymers. J Polym Mater 25: 35-50.

45. Sabir T, Carraher C (2006) Synthesis of triphenylantimony and triphenylbismuthcontaining polyether amines containing acyclovir. J Polym Mater 4: 403-413.

46. CarraherCE, Truong NT, Roner MR (2003) Synthesis of organoarsenic, organoantimony, and organobismuth poly (ether esters) from reaction with glycyrrhetinic acid and their preliminary activity against pancreatic cancer cell lines. JCAMS 1: 134-150.

47. Carraher C, Roner MR, Mosca F, Moric-Johnson A, Miller L, et al. (2017) Synthesis and characterization, including cancer cell line inhibition, of group VA (group 15)-containing polyesters from reaction with camphoric acid. $J$ Inorg Organomet Polym Mat 27: 1627-1639.

48. Carraher C, Roner MR, Black K, Frank J, Moric-Johnson A, et al. (2017) Polyesters from reaction of 3,5-pyridinedicarboxylic acid and group V-containing dihalides and their preliminary and comparative ability to inhibit cancer cell growth. Int $J$ Applied Pharma Biol Res 2: 1-17.

49. Carraher C, Roner MR, Frank J, Moric-Johnson A, Miller L, Black K, Slawek P, Mosca F, Einkauf J, Russell F. et al. (2017) Synthesis of water soluble group 4 metallocene and organotin polyethers and their ability to inhibit cancer. Processes 5: 1-13.

50. Gerasimov A, Ziganshin M, Gorbatchuk V, Usmanova L (2014) Increasng the solubility of dipyridamole using polyethylene glycols. Int J Pharm Sci 6: 244-247.

51. Lee M, Kim SW (2005) Polyethylene glycol-conjugated copolymers for plasmid DNA delivery. Pharm Res 22: 1-10. [Crossref]

52. Ansari M (2015) Investigations of polyethylene glycol mediated ternary molecular inclusion complexes with beta cyclodextrin. J Applied Pharm Sci 5: 26-31.

53. Carraher C, Barot G, Shahi K, Roner MR (2007) Synthesis, structural characterization, and ability to inhibit cancer cell growth of a series of organotin poly(ethylene glycols). J Inorg Organometal Polyms 17: 595-603.

54. Carraher C, Roner MR, Barot G, Shahi K (2014) Comparative anticancer activity of water-soluble organotin poly (ethylene glycol) polyethers. J Polym Mater 31: 123-133.

55. Carraher C, Barot G, Shahi K, Roner MR (2013) Influence of DMSO on the inhibition of various cancer cells by water soluble organotin polyethers. J Chin Adv Mater Soc 1: 294-304

56. Carraher C, Roner MR, Reckleben L, Black K, Frank J, et al. (2016) Synthesis, structural characterization and preliminary cancer cell line results for polymers derived from reaction of titanocene dichloride and various poly (ethylene glycols). J Macromol Sci 53: 394-402.

57. Carraher C, Roner MR, Black K, Frank J, Moric-Johnson A, et al. (2018) Synthesis, structural characterization and initial anticancer activity of water soluble polyethers from hafnocene dichloride and poly (ethylene glycols). J Chin Adv Mater Soc [In Press]

Copyright: (C2018 Charles EC . This is an open-access article distributed under the terms of the Creative Commons Attribution License, which permits unrestricted use, distribution, and reproduction in any medium, provided the original author and source are credited. 